\title{
ANALYSIS OF PSYCHOTROPIC MEDICINES TRIAZOLAM, ESTAZOLAM AND ALPRAZOLAM MIXTURE USING HIGH-PERFORMANCE LIQUID CHROMATOGRAPHY METHOD
}

\author{
(C) Y. Kravchuk, M. Marksa, A. Zevzikoviene, A. Zevzikovas
}

\begin{abstract}
Отруєння бензодіазепінами, особливо тріазоламом, естазоламом і алпразолама, зазвичай ие пов'язано з прийомом препарату в більших дозах, ніж це передбачено. Таким чином, для ивидкого визначення причини, щзо викликала отруєння, потрібні вибіркові і ефективні методи аналізу.

Методи. Для дослідження були обрані бензодіазепіни тріазолам, естазолам $і$ алпразолам. Аналіз проводили з використанням хроматографа «Waters 2695» з детектором фотодіодною матриці (Waters 996 з довжиною хвилі 200-400 нм), хроматографічною колонкою АСЕ C18 (2.1 мм ×5.0 см, 5 мкм), градіснтним елюентом (буфер сірчаної кислоти 0.1\% і ACN), витрата елюента 0.1 мл/хв $i$ обсяг вприскування 10 мкл.

Результати. Методика ідентифікації та кількісного визначення тріазолама, естазолама, алпразолама $i$ їх суміші була розроблена з використанням еталонних розчинів. Перевірена методика була адаптована для ідентифікачії та кількісного визначення тріазолама, естазолама, алпразолама в лікарських nрепаратаx.

Висновки. Обрана методика підходить для кваліфікачї і кількісного визначення лікарських препаратів: хроматографічна колонка АСE C18 (2.1 мм х 5.0 см, 5 мкм), градієнтний потік елюента (буфер сірчаної кислоти 0.1\% і ACN), швидкість потоку елюенту 0.1 мл/хв, об'єм ін'єкції 10 мкл $і$ детектор діодної матриці. Суміш компонентів була досліджена, $і$ час утримування було зазначено наступним чином: алпразолам (13,216 хв), естазолам (13,407 хв) і тріазолам (14,340 хв). Час утримування при повторенні аналізу не перевищував відносної похибки $р<0.05$.

Межі виявлення алпразоламу становить 0.01 мкг/мл, естазоламу 0.012 мкг/мл, тріазоламу 0.020 мкг/мл. Ліміт кількісного визначення алпразоламу становить 0.022 мкг/мл, естазоламу 0.025 мкг/мл, тріазоламу 0.045 мкг/мл
\end{abstract}

Ключові слова: тріазолам, естазолам, алпразолам, високоефективна рідинна хроматографія, якісне $i$ кількісне визначення

\section{Introduction}

According to the Baltic Statistic Medicines report in the Baltic countries (Estonia, Latvia and Lithuania) the last four-year consumption 2013, 2014, 2015, 2016 the general usage of antipsychotic drugs had a tendency of augmentation by DDD/1000/day. According to data, Lithuania remains the leading country in usage of triazolam and estazolam, however Estonia shows the greatest report in usage of hypnotics and sedatives [1]. As benzodiazepines is one of the class, which is commonly prescribed, it has shown very high percentage of self-poisoning due to inappropriate drug high dosage $[2,3]$. Due to different levels of sedation, benzodiazepines produce different toxicity.

\section{Formulation of the problem}

Poisoning of benzodiazepines, particularly triazolam, estazolam and alprazolam usually is caused by consumption of the drug in bigger doses than prescribed, however it is very unusual to cause death, unless the drug is used simultaneously with other drugs, those include alcohol, barbiturates, opioids or tricyclic antidepressant which may lead to severe health consequences such as coma or death. Common it is very rare to result in death after hospital admission [4, 5]. So, for the fast determination of material caused poisoning, selective and effective methods of analysis are requested.

\section{Analysis of recent studies and publications}

HPLC is used for the qualitative and quantitative determination of benzodiazepines. Most benzodiazepines are determined at $230 \mathrm{~nm}$, nitro- benzodiazepines at 240 $\mathrm{nm}$. For a more clear identification, diode-matrix detection is required [6, 7]. Scientific literature has described various methodics for the HPLC, which was to investigate the alprazolam, estazolam or triazolam. Clark's analysis [8] describes 5 diffferent methodics for analysis of alprazolam and triazolam, but there are no information about analysis of estazolam. In UNODC all three substances were identified, but not quantificated [9]. In other publications data about analysis of separate compounds was found. Moreover retention times in these systems are very close, so the analysis of the mixture using described methods are not possible [10-13]. \section{problem}

4. Allocation of unsolved parts of the general

The analysis of the literature data showed that alprazolam, triazolam and estazolam have been analysed as separate compounds, but not as components of mixture.

So it was decided to use literature data as a base and establish HPLC methodic that was suitable for all three substances and for their mixture too. 


\section{Formulation of goals (tasks) of Article}

To make the toxicological laboratory work more efficient and practical, methodic which would allow to identify several substances performing only one analysis is very important. The aim of experiment: to optimize HPLC methodic, suitable for triazolam, estazolam and alprazolam qualitative and quantitative evaluation.

\section{Materials and methods}

The object of investigation: alprazolam, estazolam and triazolam and their mixture.

Reference and test solutions. Reference solutions of the tested substances have been prepared all by dissolution of the standard in methanol. 3 standard solutions of concentration of $0,1 \mathrm{mg} / \mathrm{ml}$ have been prepared: reference solution alprazolam (Sigma-Aldrich, USA), estazolam (Sigma-Aldrich, USA), triazolam (Sigma-Aldrich, USA). Reference solutions: alprazolam RSA2, estazolam RSE2, triazolam RST2. A reference mixture solution was prepared consequently (RS MAET2) by using $1 \mathrm{ml}$ of each standard solution to be prepared. Test solutions for analysis have been prepared from the medicinal products obtained at the pharmacy stores in Lithuania. Test solutions of concentration of $0.1 \mathrm{mg} / \mathrm{ml}$ were prepared respectively: alprazolam (A2) was produced from medicinal product "Xanax" $1 \mathrm{mg}$ tablets (Pfizer H.C.P), Estazolam solution (E2) - "Estazolam TC" $2 \mathrm{mg}$ tablets (Polfa Tarchomin), Triazolam solution (T2) - "Halcion" $250 \mu \mathrm{g}$ (Pfizer H.C.P) tablets. The tablet has been crushed and grinded well in the mortar. The powder obtained has been transferred to volumetric flask and dissoluted with methanol. Further the suspension has been mixed well for $10 \mathrm{~min}$. with a help of an ultrasound bath. The obtained precipitate has been separated by centrifuge. The solution has been filtrated using PVDF filter with pore size of $0,45 \mathrm{~mm}$. The resulting solution has been transferred to cork closed flask and used for upcoming investigations. A mixture solution was prepared consequently (RS AET2) by using $1 \mathrm{ml}$ of each solution of test substances.

Methodology: chromatographic analysis was performed using chromatograph „Waters 2695“ with a photodiode array detector (Waters 996, at wavelength 200-400 nm range). Mixture solution separation has been performed using chromatographic column ACE C18 $(2.1 \mathrm{~mm} \times 5.0 \mathrm{~cm})$ with sorbent particle size of $5 \mu \mathrm{m}$. As the mobile phase have been used: acetonitrile, purified water, sulfuric acid buffer $0.1 \%$ aqueous solution. A mixture of solutions has been prepared from alprazolam, estazolam, triazolam by taking $2.2 \mathrm{ml}$ each of them and preparing 6 samples, which were consequently diluted each time by $2.2 \mathrm{ml}$ of methanol. The initial mixture solution from all three tested preparations with concentration of $0.1 \mathrm{mg} / \mathrm{ml}$ has been prepared as well. The mixture has been analyzed by high performance liquid chromatography under optimized conditions. Alprazolam, estazolam and triazolam mixture RS MAET2, which has been prepared from standard solutions, for analysis by HPLC methodic required to optimize the composition of the eluent and the elution method (isocratic or gradient mode). Injection volume has been stated for $10 \mu \mathrm{l}$. Alprazolam, estazolam and triazolam mixture have been identified by UV absorption spectrum, light absorption at a range from 200-600 nm wavelength.

Validation: For validation process following parameters has been chosen: specificity, repeatability, precision, limits (LOD and LOQ).

\section{Results}

A detector DAD - Diode Array Detection (SPDM20A) has been used. With the help of this detector the absorption peaks of analytes were determined using UV light $(200-600 \mathrm{~nm})$ in the appropriate UV light spectrum. Therefore a qualitative evaluation of the mixture components can be performed. Accounting this criteria, as well as an appropriate retention time chosen we can reach a high accurate qualitative assessment of mixture to be tested. In order to determine the most appropriate chromatography column, investigated medicinal products mixture (RSAET 2) was tested using columns: Sunfire C18 (length $15 \mathrm{~cm}$, internal diameter $3.0 \mathrm{~mm}$, sorbent particle size $3.5 \mu \mathrm{m}$ ), Supelco LC18 (length $15 \mathrm{~cm}$, inner diameter $4.6 \mathrm{~mm}$; sorbent particle size of $5.0 \mu \mathrm{m}$ ) and an ACE C18 (length $25 \mathrm{~cm}$, inner diameter $4.6 \mathrm{~mm}$, sorbent particle size $5 \mu \mathrm{m})$. The best determination has been achieved using the ACE C18 chromatography column $(25 \mathrm{~cm} \times 4 \mathrm{~mm} \times 5 \mu \mathrm{m})$. In order to separate and to identify the drug substance components of the medicinal products solution, we have analyzed the mixture solution (RSAET2) by chromatography tests using different eluents systems. Experiments did not reach the maximum isolation, using the literature described conditions; therefore it was necessary to modify the systems in order to get optimal results. The solvent system was evaluated by the retention time of the analytes, the symmetry of the peaks and baseline stability. Alprazolam, estazolam and triazolam mixture separation was achieved by elution with solvent system consisting of $0.1 \%$ sulphuric acid aqueous solution (A) and acetonitrile (B) and change the quantitative composition gradient (proportions described in the Table 1).

Examination of separation of mixture was performed when the mobile phase flow rate was $0.1 \mathrm{ml} / \mathrm{min}, 0.2 \mathrm{ml} / \mathrm{min}$ and $0.4 \mathrm{ml} / \mathrm{min}$. The optimal separation was observed when the flow rate of the eluent was $1,0 \mathrm{ml} / \mathrm{min}$. General chromatographic analysis duration was 29 minutes.

High performance liquid chromatography method was validated according to selected settings - specifity, precision, linearity, limit of detections and limit of determination.

Method of specificity is a methodic of distinguishing the tested substances from impurities and other material, which can be present in the prepared drug composition. Tested mixtures separation has been improved using HPLC methodic with photodiode array detector. Analyte specificity is demonstrated by comparing the standard and analyte retention time and spectral overlaps.

1.Chromatogram of the medicinal products mixture (Fig. 1). We can see that alprazolam retention time is $13.216 \mathrm{~min}$, estazolam - $13.407 \mathrm{~min}$, and triazolam $-14.340 \mathrm{~min}$. 
2.Comparison of the UV light spectrum absorbance's chromatogram to the absorption spectrum in literature sources (Fig. 2-4).
3. Chromatogram obtained from reference mixture solution (Fig. 5).

Analytical characteristics of HPLC method validation data shown in Table 2.

Table 1

Eluent quantitative composition gradient variation over time

\begin{tabular}{|c|c|c|c|}
\hline Chromatography time (min) & Eluent speed (ml/min) & Sulfuric acid buffer 0,1\%(A) & ACN-Acetonitrile(B) \\
\hline $00: 00$ & 1.0 & 98.0 & 2.0 \\
\hline 1 & 1.0 & 98.0 & 2.0 \\
\hline 20 & 1.0 & 2.0 & 98.0 \\
\hline 23 & 1.0 & 2.0 & 98.0 \\
\hline 24 & 1.0 & 98.0 & 2.0 \\
\hline 29 & 1.0 & 98.0 & 2.0 \\
\hline
\end{tabular}

mAU

Chromatogram

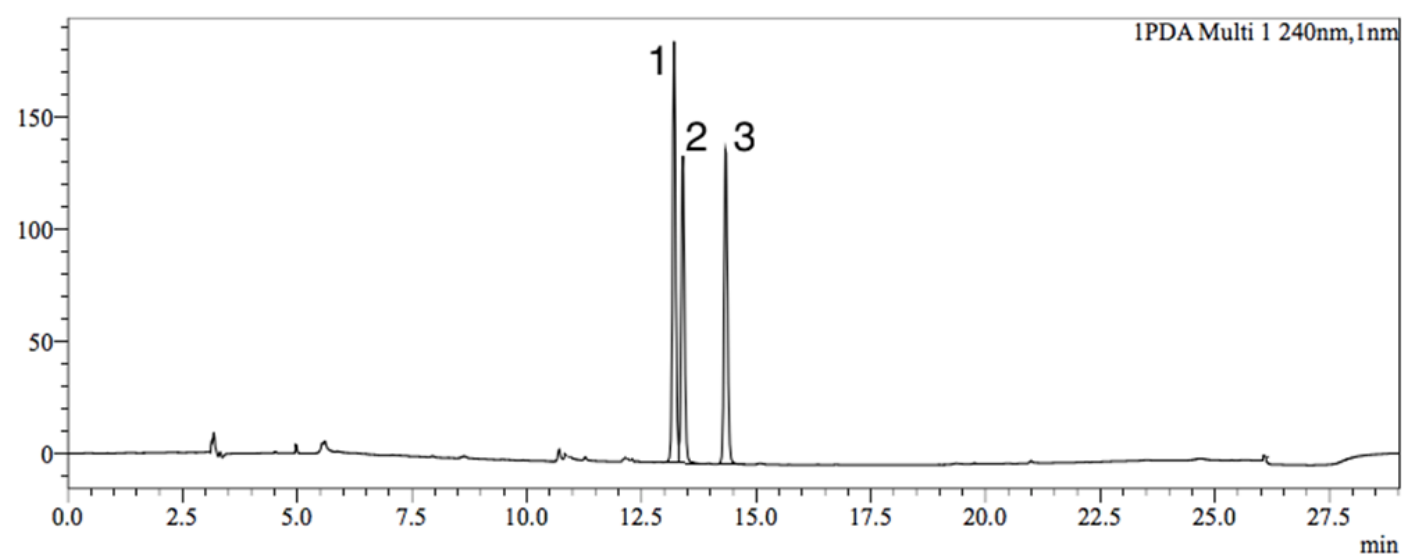

Fig. 1. Medicinal products mixture (RSAET2) chromatogram: 1 - Alprazolam (retention time 13,216 min.); 2 - Estazolam (13,407 min.); 3 - Triazolam (14,340 min.)

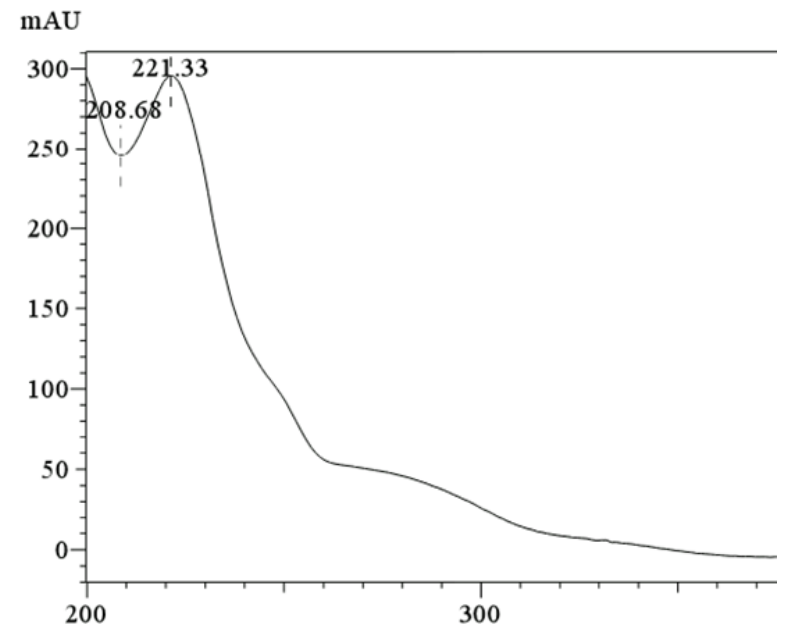

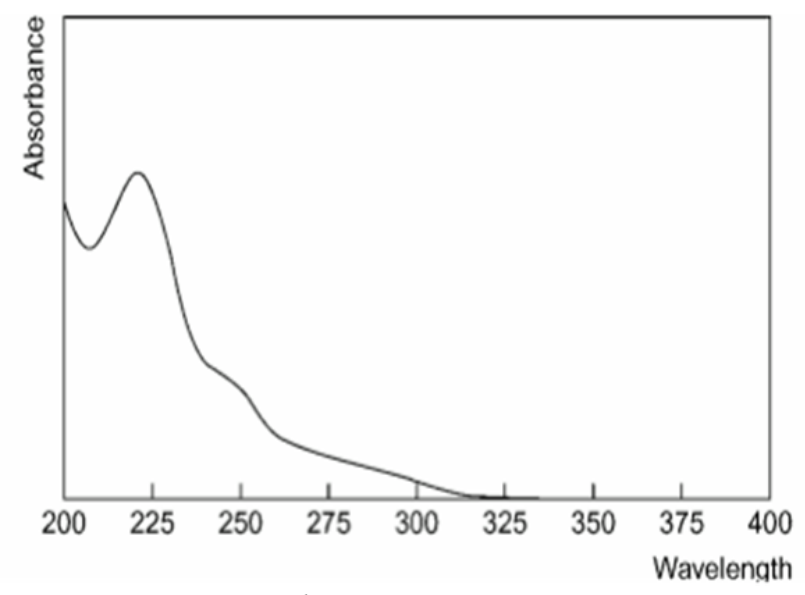

$b$

Fig. 2. Alprazolam absorbance spectrum: $a$ - obtained by measurement with DAD detector; $b$ - obtained from „Clarke`s Analysis of Drug and Poisons" 

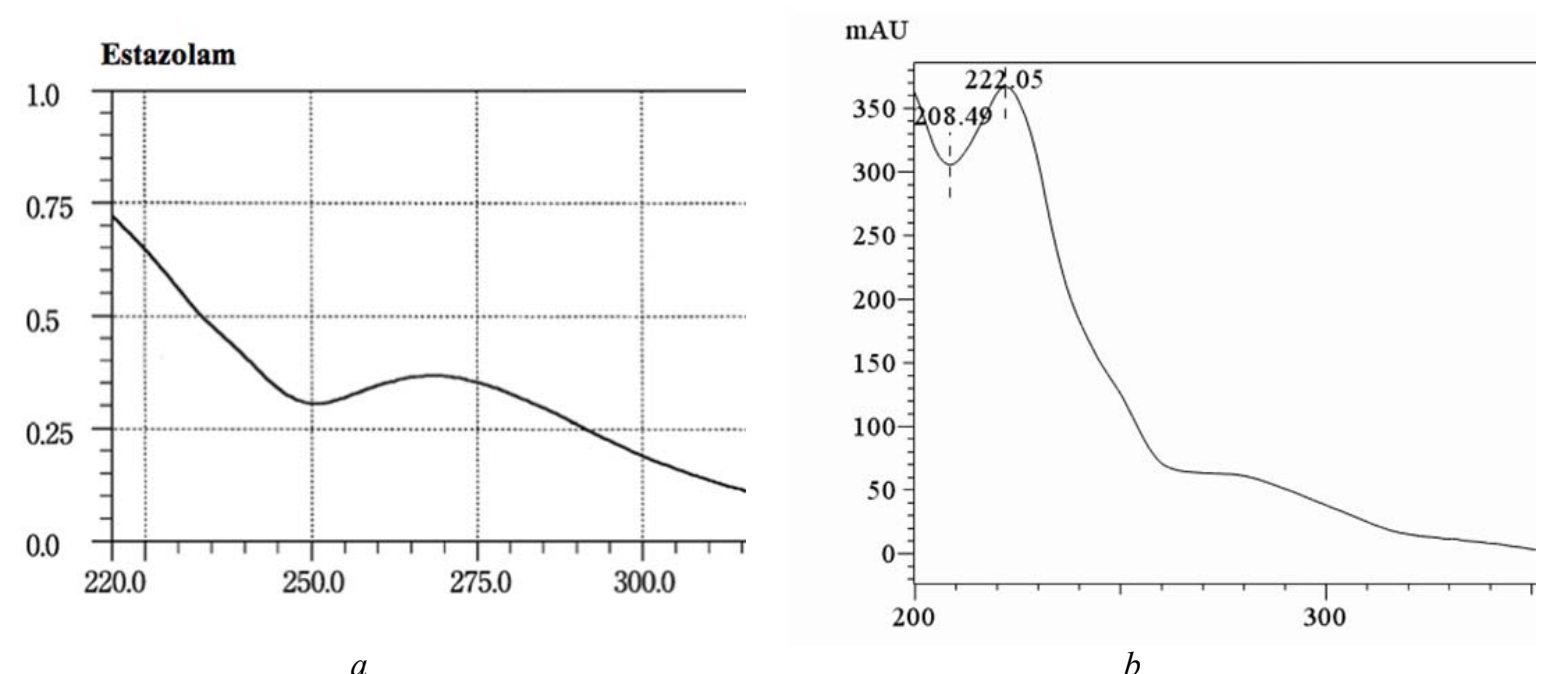

Fig. 3. Estazolam absorbance spectrum: $a$ - obtained by measurement with DAD detector; $b$-obtained from Japanese Pharmacopoeia $16^{\text {th }}$ edition

mAU
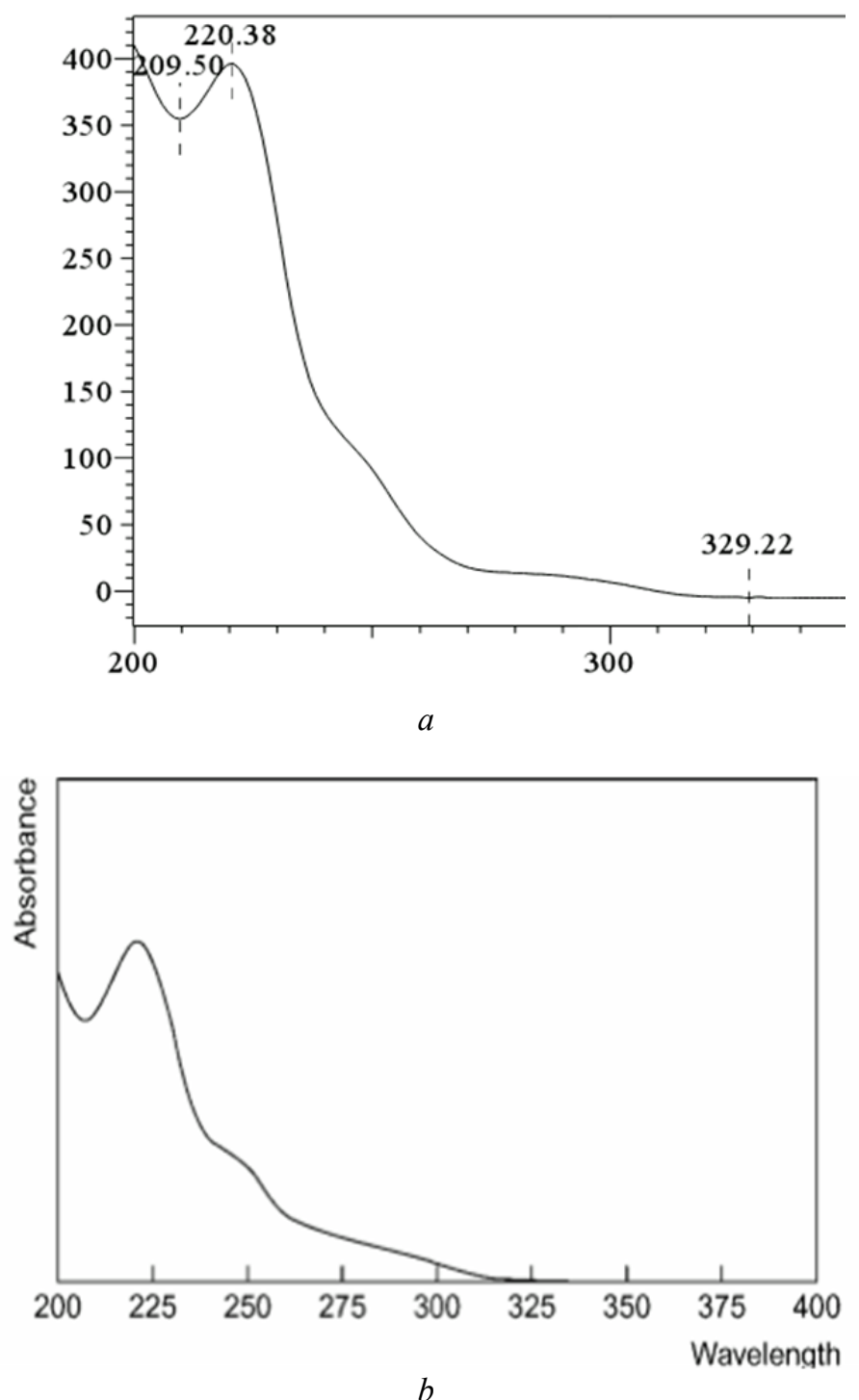

Fig. 4. Triazolam absorbance spectrum: $a$ - obtained by measurement with DAD detector; $b$ - obtained from „Clarke`s Analysis of Drug and Poisons" 
mAU Chromatogram

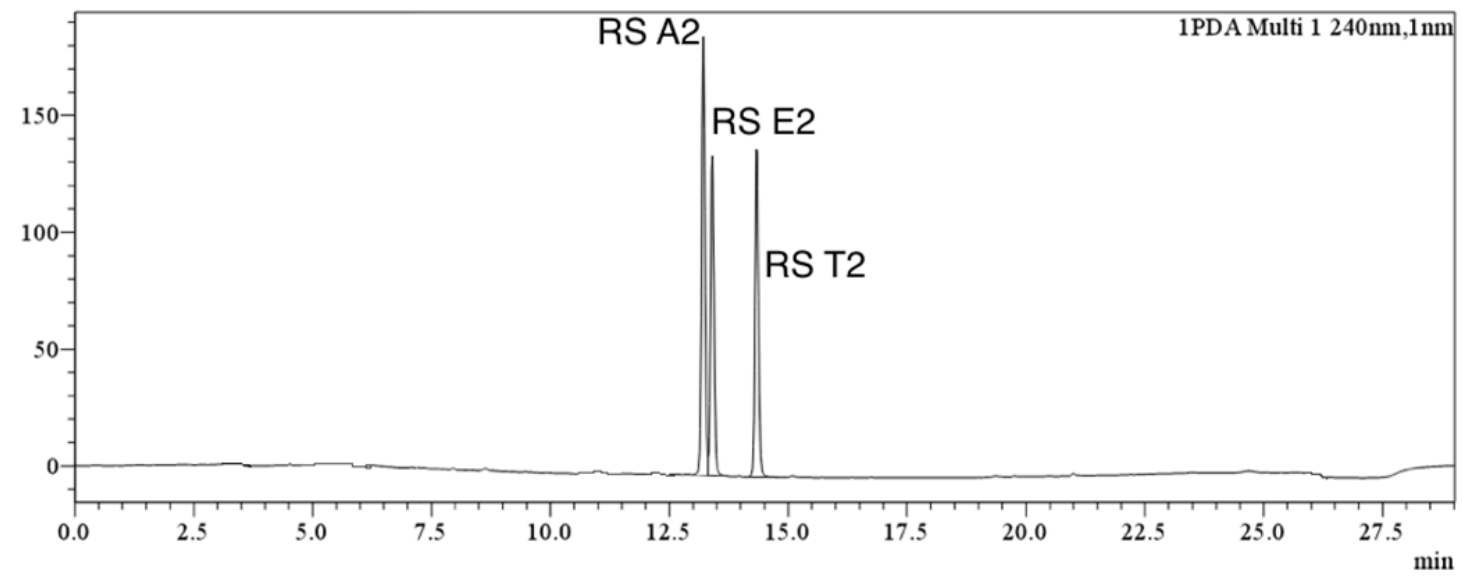

Fig. 5. Reference mixture solution (RS MAET2) chromatogram: RS A2 - Alprazolam (retention time 13.216 min.), RS E2 - Estazolam (13.407 min.), RS T2 - Triazolam (14,340 min.)

Table 2

Analytical characteristics of HPLC method validation data.

\begin{tabular}{|c|c|c|c|c|c|c|c|c|c|}
\hline \multirow{2}{*}{$\begin{array}{c}\text { Tested } \\
\text { solution }\end{array}$} & \multirow{2}{*}{$\begin{array}{c}\mathrm{t}_{\mathrm{R}} \\
\mathrm{min}\end{array}$} & \multicolumn{2}{|c|}{$\begin{array}{l}\text { Intraday } \\
\text { RSD (\%) }\end{array}$} & \multicolumn{2}{|c|}{$\begin{array}{l}\text { Interday } \\
\text { RSD (\%) }\end{array}$} & \multirow{2}{*}{$\mathrm{R}^{2}$} & \multirow{2}{*}{ Regression equation } & \multirow{2}{*}{$\begin{array}{l}\text { LOD } \\
(\mu \mathrm{g} / \mathrm{ml})\end{array}$} & \multirow{2}{*}{$\begin{array}{c}\text { LOQ } \\
(\mu \mathrm{g} / \mathrm{ml})\end{array}$} \\
\hline & & $\mathrm{a}$ & $\mathrm{b}$ & $\mathrm{a}$ & $\mathrm{b}$ & & & & \\
\hline Alpr & 13,22 & 2,5 & 0,052 & 9,0 & 0,054 & 0,9999797 & $07 * x+1989.43$ & 0,01 & 0,022 \\
\hline Estazc & 13,41 & 3,0 & 0,051 & 8,5 & 0,053 & 0,9999596 & $f(x)=1.41288 \mathrm{e}+007 * x+5012.14$ & 0,012 & 0,025 \\
\hline Triazolam & 14,34 & 3,5 & 0,026 & 5,2 & 0,028 & 0,9999613 & $f(x)=1.13786 e+007 * x+3775.44$ & 0,020 & 0,045 \\
\hline
\end{tabular}

Note: $t_{R}$ : retention time, $R S D$ : relative standard deviation a) by peak area, b) by retention time; $R 2$ : correlation coefficient, LOD: limit of detection, LOQ: limit of quantitation

Once the optimum conditions were set at which can be identified alprazolam, estazolam and triazolam in the mixture, the methodology was applied in test solutions A2, E2 and T2 prepared from medicinal products obtained at the pharmacy stores located in Lithuania. Examination of medicinal products were identified by the following criteria: a retention time and UV light absorption spectrum. For all medicinal products retention times were close to the reference solution and UV absorption spectra were identical to the literature data.

In order to assess the suitability of selected HPLC methodic for the quantitative determination of test materials calibration curves of light absorption peak height dependence on substance concentration were prepared. The higher the tonnage, the higher peak. The produced standard solutions were prepared at different concentrations to create calibration curve solutions by diluting standards in half. Curve was made from 6-point concentration range of 0.000937 $\mathrm{mg} / \mathrm{ml}-0.03 \mathrm{mg} / \mathrm{ml}$.

\section{Conclusion}

1. The most suitable chromatographic conditions were established: ACE C18 $(2.1 \mathrm{~mm} \times 5.0 \mathrm{~cm}, 5 \mu \mathrm{m})$ chromatographic column, gradient eluent flow (sulfuric acid buffer $0.1 \%$ and $\mathrm{ACN}$ ), eluent flow rate $0.1 \mathrm{ml} / \mathrm{min}$, injection volume of $10 \mu \mathrm{l}$ and diode array detector. Mixture of components has been examined and retention times have been stated as follows: alprazolam (13.216 $\mathrm{min})$, estazolam (13.407 $\mathrm{min})$ and triazolam (14.340 min). Retention time upon repetition of analysis have not exceeded the relative error of $\mathrm{p}<0.05$ limitation.

2. Validated methodics was proven to be suitable for the medicinal products of "Xanax" (Pfizer H.C.P), "Estazolam TC" (Polfa Tarchomin), "Halcion" (Pfizer H.C.P) qualitative assessment.

3. Applied high performance liquid chromatography has been used to perform calibration curve from the resulting alprazolam, estazolam and triazoliam qualitative evaluation, and therefore has shown that limits of detection of alprazolam is $0.01 \mu \mathrm{g} / \mathrm{ml}$, estazolam $0.012 \mu \mathrm{g} / \mathrm{ml}$, triazolam $0.020 \mu \mathrm{g} / \mathrm{ml}$. Limit of quantification of alprazolam is $0.022 \mu \mathrm{g} / \mathrm{ml}$, estazolam $0.025 \mu \mathrm{g} / \mathrm{ml}$, triazolam $0.045 \mu \mathrm{g} / \mathrm{ml}$.

\section{References}

1. Medicines consumption in Lithuania. 2017. URL: http://www.vvkt.lt/Front-Page

2. Hobelmann J. G., Clark M. R. Benzodiazepines, Alcohol, and Stimulant Use in Combination with Opioid Use / ed. by Staats P., Silverman S. // Controlled Substance Management in Chronic Pain. Cham: Springer, 2016. P. 75-86. doi: http://doi.org/10.1007/978-3-319-30964-4_6 
3. The American Psychiatric Publishing Textbook of Substance Abuse Treatment / ed. by Galanter M., Kleber H. D., Brady K. T. Washington: American Psychiatric Publishing, 2014. doi: http://doi.org/10.1176/appi.books.9781615370030

4. Lippincott Illustrated Reviews: Pharmacology / ed by Harvey R. A. et. al. Lippincott Williams \& Wilkins, 2009. 564 p.

5. Tsutaoka B., Olson K. R. Chapter 31. Benzodiazepines // Poisoning \& Drug Overdose. McGraw-Hill, 2012. URL: https://mhmedical.com/Content.aspx?bookId=391\&sectionId=42069845

6. A rapid ultrasound-assisted dispersive liquid-liquid microextraction followed by ultra-performance liquid chromatography for the simultaneous determination of seven benzodiazepines in human plasma samples / Fernández P. et. al. // Analytica Chimica Acta. 2013. Vol. 767. P. 88-96. doi: http://doi.org/10.1016/j.aca.2013.01.016

7. Mistry K., Grinberg N. Application of Monolithic Columns in High Performance Liquid Chromatography // Journal of Liquid Chromatography \& Related Technologies. 2005. Vol. 28, Issue 7-8. P. 1055-1074. doi: http://doi.org/10.1081/jlc-200052972

8. Moffat A. C., Osselton M. D., Widdop B. Clarke's Analysis of Drugs and Poisons. London: Pharmaceutical Press, 2011. $2473 \mathrm{p}$.

9. Collection of analytical data for benzodiazepines and benzophenones / Japp M. et. al. // Journal of Chromatography A. 1988. Vol. 439, Issue 2. P. 317-339. doi: http://doi.org/10.1016/s0021-9673(01)83844-9

10. Screening procedure for benzodiazepines in biological fluids by high-performance liquid chromatography using a rapidscanning multichannel detector / Mura P. et. al. // Journal of Chromatography B: Biomedical Sciences and Applications. 1987. Vol. 416. P. 303-310. doi: http://doi.org/10.1016/0378-4347(87)80513-3

11. Theis D. L., Bowman P. B. Development of a liquid chromatographic method for the determination of triazolobenzodiazepines // Journal of Chromatography A. 1983. Vol. 268. P. 92-98. doi: http://doi.org/10.1016/s0021-9673(01)95391-9

12. High performance liquid chromatographic analysis of basic drugs on silica columns using non-aqueous ionic eluents / Flanagan R. J. et. al. // Journal of Chromatography A. 1982. Vol. 247, Issue 1. P. 15-37. doi: http://doi.org/10.1016/s00219673(00)84853-0

13. Chiarotti M., De Giovanni N., Fiori A. Analysis of benzodiazepines: I. Chromatographic identification // Journal of Chromatography A. 1986. Vol. 358. P. 169-178. doi: http://doi.org/10.1016/s0021-9673(01)90326-7

Дата надходження рукопису 14.08.2018

Yelyzaveta Kravchuk, Postgraduate student, Department of Analytical and Toxicological Chemistry, Lithuanian University of Health Sciences, Sukilèlių str., 13, Kaunas, Lithuania, 50162

E-mail: yelizavetak23@gmail.com

Mindaugas Marksa, Lecturer, Department of Analytical and Toxicological Chemistry, Lithuanian University of Health Sciences, Sukilèlių str., 13, Kaunas, Lithuania, 50162

E-mail: minzedas@gmail.com

Augusta Zevzikoviene, PhD, Associate Professor, Department of Analytical and Toxicological Chemistry, Lithuanian University of Health Sciences, Sukilèlių str., 13, Kaunas, Lithuania, 50162

E-mail: augustazev@gmail.com

Andrejus Zevzikovas, PhD, Associate Professor, Department of Analytical and Toxicological Chemistry, Lithuanian University of Health Sciences, Sukilèlių str., 13, Kaunas, Lithuania, 50162

E-mail: andrejuszevzikovas@gmail.com 